his residence, Exmouth (Devon), on March 25th, in his fiftyeighth year. The deceased officer, who graduated M.D., M.Oh. of the Royal University of Ireland in 1871, entered the Bengal department of the Indian Medical Service in March, 1872, and became surgeon-colonel in June, 1902. He retired in 1905 and took up his residence at Exmouth.

Deputy Inspector-General W. J. Baird, R.N. (retired), recently, at Brighton. He was assistant surgeon of the Leander in the Black Sea througbout the Crimean war and was "lent" to various ships during the cholera epidemic of 1854 ; he landed to attend to the wounded after the battle of Alma and served with the Naval Brigades at Enpatoria and before Sebastopol (Crimean and Turkish medal, Sebastopol clasp); served with the 1st Battalion of Royal Marines during the Chinese war 1857-59 and was acting surgeon of the Assistance while used as a hospital ship off Canton; present at the attack of the Bravas near the White Blend Mountains, and at the capture of the bridge and village of Sheek-lsing; was landed in medical charge of Marines during the attack on the Peiho forts, specially mentioned in despatches (China medal, Oanton clasp); surgeon of the Spiteful in the West Indies during the epidemic of yellow fever, 1861 ; served in the Druid, on the West Coast of Africa throughout the Ashantee war, 1873-74, was present at the destruction of Elmna and several villages on the coast, and medical officer of health afloat at Cape Coast Castle (Ashantee medal).

\section{ARMY SANITATION.}

A correspondent writing in the Times of April 3rd says : "The statistics of mortality dne to disease in the South African war, when compared with the losses more recently suffered by the Japanese from the same causes, demonstrated only too clearly that in the matter of sanitation there was in the British army considerable room for improvement. It is, therefore, satisfactory to find that the matter has been thoroughly taken in hand by the Army Council and a series of regulations issued, which should bear good fruit in our future campaigns. Under the direction of authority, a manual of sanitation has been prepared the contents of which the combatant officer will not only have to be acquainted with, but will have to submit to have his knowledge therein tested by examination. ...... On the outbreak of war there will be formed for service in the field a committee, consisting of a combatant field officer as president, with a field officer R.E. and a field officer R.A.M.O. as members. This committee will act under the orders of the general officer commanding-in-chief, and its duties will be to ascertain that sanitary appliances and materials of all kinds required for the army are forthcoming, and that an adequate reserve is maintained."

Journal of THE Royal ARMy Medical Corps.

The March number of this journal is a very good one. We would particularly call attention to the very interesting paper on Recent Researches into the Epidemiology of Malta Fever, by Colonel David Bruce, C.B., F.R.S., which was read before the Epidemiological Society on Feb. 15th last. It is a brief and, at the same time, exbaustive and practical exposition of all that is known in regard to this disease.

Revised regulations regarding the Indian Medical Service have now been issued.

\section{Cortespondence.}

\section{"Audi alteram partem."}

\section{THE WATER-SUPPLY OF CATRO.}

\section{To the Editors of THE LANCET.}

Sins,-My attention has been drawn to a letter in THE LANCET of Jan, 26th, p. 251, over the signature of Mr. John M. Robertson, M.P., which deals in part with the question of the Cairo water-supply and more particularly as regards the quality of the water supplied by the company to the town of Cairo. I much regret I had not the opportunity of meeting the writer during his short visit to this country, as I should have been only too happy to have given him all the information in my power as regards the Cairo water-supply and so have saved him the annoyance of finding he had been misinformed by someone who evidently has no knowledge of the existing state of affairs. The remarks he makes would, to a great extent, have been correct three or four years ago, at which time the town was supplied with water taken direct from the Nile and filtered through sand filters, when the water was of poor quality as regards purity, especially during low Nile, and as regards clearness during the high Nile.

In 1903 the question of improving the supply was seriously taken in hand and experiments were made with a view to finding a pure source. The borings made by the water company showed that there existed an underground stream and the tests which were made showed that underground water taken from deep bore boles was of great purity, both chemically and bacteriologically, and since then the whole supply has been remodelled and a completely new pumping station has been erected taking the water from deep bore wells, about 200 feet deep. The water is of exceptional purity and is always clear as crystal on its arrival at the surface. The whole of Cairo's drinking and domestic supply is now pumped from these wells, and Nile water is only used for road-watering and gardens. Even for this purpose the Nile water-supply will, however, be entirely superseded by well water in the course of about 12 months from date, when all the wells are completed. In his letter Mr. Robertson says that in the police schools the drinking water is very carefully filtered. This is possibly the case, but it is quite unnecessary and, as a matter of fact, I understand that the Government officials and experts contend that the water taken direct from the company's mains is so pure that it is only liable to be deteriorated by manipulation, such as filtering or boiling, unless great care is taken as to the cleaning of the vessels employed. Again, not only is the drinking water of the town not "officially recognised to be bad," but the water now being supplied has been officially accepted by the Government as of pure and excellent quality for domestic purposes. This can easily be proved by applying to the authorities. Again, it is not discoloured at high Nile, but is of the same clearness all the year round.

As you will see from the above statements, which can be verified by application to the local authorities, his letter gives quite a false impression of the existing state of the Cairo water-supply, and in fairness to my company I shall be mucl obliged if you will publish this letter in THE LANCET at. the first opportunity.

$$
\text { I am, Sirs, yours faithfully, }
$$
AstuEY P. FRIEND,

Cairo, March 21st, 1907 Manager, Cairo Water Company.

\section{GRADUATED LABOUR IN SANATORIUMS。}

\section{To the Editors of THE LANCET.}

SrRs,-Naturally enough, when one reads remarks by Dr. T. D. Lister and Mr. C. H. Garland and Dr. M. S. Paterson, ${ }^{1}$ one pays respectful attention to the conclusions come to by those well qualified to judge as to what really is the best thing to be done for the working. class consumptive. Recent work has been useful especially in clearing the subject of after-treatment of those preconceptions which had led to what Sir $\mathbb{R}$. Douglas Powell calls "airy and unpractical advice." But one sees in one or two appreciations of such inquiries a certain note of enthusiasm as to the heavy nature of the work which may be expected of public sanatorium patients, and with such beneficial results, according to these authors that it seems a natural inference that the better off should surely be given a chance of participation as well. For it is, of course, a fact that at nearly all private sanatoriums anything in the nature of hard exercise is forbidden even for the most robust patients.

Now let me from experience gained by residence in two public and four private sanatoriums try to point out a reason or two why it is likely that the teaching of the latter as to exercise is the correct one so far as absolute therapeutic value goes. I think that they should give pause to the enthusiasms just noticed. In the first place, if the private patient is forbidden violent exercise it is with no idea of pleasing him, for the average upper middle-class patient whether male or female, often wishes nothing so much as to continue some favourite game or sport. When he leaves. -and his state then if his condition has allowed walking exercise is by no means "soft" -he often breaks rules as to exercise laid down for him and, as many sanatorium physicians seem to think, has to return as a more or less direct consequence of this, and I cannot 
suppose that the suddenness of indulgence in unaccustomed exercise is the main factor in the breakdown. One has seen made the most cautious and persevering attempts to resume some favourite exercise with quite unsatisfactory results. Then there is this point, that the private sanatorium physician has a much harder therapeutic task and gains thereby a more detailed insight into treatment. If a man comes to one because he is not getting on as quickly as he would like (and the laity have remarkably exacting views as to this) in a hut in his grounds, it is very obviously more difficult to improve his condition than it is that of an artisan from the town. Couple with this the fact that it is very hard to judge of the effect of the treatment in phthisis, especially in improving cases. If a patient gets on well while digging unbroken ground it by no means follows that he would not do better with gentle uphill walking. Let us not, forget the natural intermissions of the disease or the fact that the test of an alternation of current types of treatment is one which is never deliberately applied and which only occurs occasionally and by chance. The few instances of it which I have seen have not left me with much opinion of the absolute therapentic value of the plan of working the consumptive sound. And as to the advisability of treating patients to the best advantage, let German statistics as to final results speak. Finally, the traditions of treatment are at private sanatoriums much longer ; their physicians have fewer patients and can study them more closely, the patients themselves stop longer, and return (if they need to) much more frequently for further treatment. Opportunities of observation are therefore, on the whole, much greater, for two cases observed thoroughly asd at length teach one more than a rapid succession of 20 . If, then, with these advantages for judging private sanatoriums pronounce against hard exercise, is it wise to be enthusiastic over physical feats by consumptives, especially if one remember the poor physique they often show?

Now, in saying all this one does not wish in the least to ram one's conclusions down anyone's throat. It is easy enough to see that under our present unfortunate social conditions the great thing is to procure the main essentials of the treatment for as many as possible of the consumptive proletariat and to prolong the working life of each as much as one can. In presence of these two objects, especially of the latter, minor therapeutic details must go by the board. But in the hard task of striking the balance of considerations one will not be at all helped (to avoid the serious errors which beset one) by the state of lay opinion likely to be promoted by sentimental preconceptions which look on the treatment of early phthisis in the working classes as muscle culture plus straight talks against loafing. If such enthusiasms be not checked, sanatorium treatment of the working man may come for a time to suffer somewhat as (with due apologies to Professor Armstrong and the Heuristic method) primary education did at Dotheboys Hall.

$$
\text { I am, Sirs, yours faithfully, }
$$
W. C. RIVers.

Crossley Sanatorium. Frodsham, March 23rd, 1907.

\section{IDIOPATHIC (MICROBIC) CYANOSIS.}

To the Editors of THE LANCET.

SIRS, - Under ordinary circumstances the letter published in your issue of March $9 \mathrm{th}$ of Dr. Samuel West and Dr. T. Wood Clarke would not call for any notice, but as my friend Dr. Carstairs $C$. Douglas has made a real addition to our knowledge it would be unjust to him to pass by any attempt to belittle its value without protest. Pat briefly, as the result of a long series of chemical and bacteriological observations on the patient whose case was fully described in our paper, Dr. Douglas found that the blood revealed the presence of methæmoglobin; that the blood, saliva, and fæces contained nitrites; that the fæces had no power of converting ox blood into methrmoglobin; that these facts raised the suspicion of a hæmatogenous formation of methæmoglobin; and that very careful investigations proved that the blood contained the bacillus coli or a very closely allied organism. With these results, as far as one case can go, we are absolutely satisfied. One positive observation is of more value than countless negative statements. We, desire, however, to obtain further opportunities of research in other patients. In this hope we made the statement : "It seems to us very desirable that these observations should not be taken as final and if opportunity presents itself they will be repeated, especially those of a bacteriological nature." Surely Dr. West and Dr. Clarke are able to appreciate the difference between a desire for further observations on a more extended series of cases and a doubt of the correctness of our results! In making this remark there is no intention to impugn the good faith of your correspondents. They simply appear to be victims of a tendency towards "terminological inexactitude." That this is probably the state of their minds may be gathered from the fact that in spite of their perusal of the Dutch literature on the subject, in which, with an imitation which may be regarded as the sincerest flattery, they have faithfally followed in our footsteps, they nevertheless make the statement that we suggest the term "microbic cyanosis" to take the place of methæmoglobinæmia. We disclaim this intention inasmuch as methæmoglobinæmia is only one form of that complex known as cganosis-true and false. The term idiopathic cyanosis, it may be added, is bad, not only because the word idiopathic is archaic, but because it has been applied to the polycythremia with splenomegaly, which has recently been so thoroughly discussed.

In conclusion, let me add that although the remarks made by Dr. West and Dr. Clarke on the careful observations of Dr. Douglas certainly require correction, it was a matter of interest to me that a case of sulph-bæmoglobinæmia had been observed in this country. It is to be hoped that the authors will have further opportunities of investigating the condition so that they may be able to add something to the observations of Dr. A. A. Hijmans van der Bergh and Mejuvrow Gatterink.

Edinburgh, March 26th, 1907 .

I am, Sirs, yours faithfully,

* * We have retained the term "idiopathic " in the heading because former letters on the subject have borne this title--ED. L.

\section{THE USE OF ALCOHOLIC BEVERAGES. To the Editors of THE LANCET.}

SIRS,-It is difficult to fathom the objects of the pronunciamiento on the alcohol question, which appears in your columns under this title, signed by 16 eminent members of the medical profession. It may be that they consider themselves the oracles of the medical profession whose opinions should be received with unreasoning credulity by their brethren. It may be very gratifying to each of them to say, "I am Sir Oracle, and, when I ope my lips, let no dog bark." On the other hand, it may be that they just wish to let us and the public know that they are still alive and have not succumbed to the baneful influence of alcohol. Whatever be the motive force I should like to remind them that we are now in the twentieth century and oracular statements are of no value whatever. If their "statement represents the opinion of the leading clinical teachers as well as of the great majorisy of medical practitioners, "then the necessity for their manifesto does not exist and it becomes a mere blatant advertisement. If, on the other hand, it be their zeal for the public weal which forces them into print, surely it is their duty to let the medical profession and the public know the reasons for the faith which is in them. If they have got one scintilla of evidence in support of their statements by all means let us have it. I am pleased to say that I know the majority of the signatories (I have nothing to say against their temperance), and $I$ know most of their writings, but $I$ do not know one of them who has ever done any experimental work of any value either on the use or abuse of alcohol. It is true that Mr. Jonathan Hutchinson has shown that it is an excellent mouth wash in cases of operation on the tongue, but he did not produce any comparative evidence as to whether it was better or worse than many other antiseptic mouth washes.

"In many cases it may be truly described as lifepreserving, owing to its power to sustain cardiac and nervous energy, while protecting the wasting nitrogenous tissues." Surely we are here on safe ground. I can scarcely think that 16 eminent men would make such a statement unless they knew what they were talking about. I have written on Alcoholic Asthenia and on the Therapeutic Uses of Alcohol, and I am extremely anxious to get reliable information as to its power to sustain cardiac and nervous energy. It won't do to tell me that they have seen severe cases of typhoid fever or pneumonia cured by brandy, because many 